INTEGRITAS : Jurnal Pengabdian

Vol 5 No 1 Juli 2021

ISSN 2580 - 7978 (cetak) ISSN 2615 - 0794 (online)

\title{
PENINGKATAN NILAI TAMBAH DAN DIVERSIFIKASI OLAHAN RUMPUT LAUT
}

\section{ADDITIONAL VALUE IMPROVEMENT AND DIVERSIFICATION PROCESSED SEA GRASS}

\author{
Sulistyaningsih \\ Fakultas Pertanian, Universitas Abdurachman Saleh Situbondo \\ Email: lis_sulistyaningsih@yahoo.com
}

\begin{abstract}
Abstrak: Tujuan dan target yang ingin dicapai dalam pengabdian ini adalah melakukan peningkatan nilai tambah rumput laut melalui kegiatan pelatihan ketrampilan dan sosialisasi. Luaran yang dihasilkan dari program ini Meningkatkan pemahaman tentang manfaat rumput laut, diversifikasi pangan dan pemenuhan gizi keluarga serta terampil membuat makanan yang berasal dari rumput laut menjadi bakso. Pelatihan ini mendapat respon yang sangat baik dari seluruh peserta. Selama pelatihan, peserta selalu datang tepat waktu dan sangat antusias dalam mendengarkan penjelasan dari para pengabdi. Para peserta juga sangat aktif dalam sesi diskusi dan banyak pertanyaan-pertanyaan yang dilontarkan. Pengetahuan mereka bertambah dengan adanya kegiatan ini dan sangat bermanfaat bagi kehidupan sehari-hari selain dapat membantu meningkatkan kemampuan ketrampilan juga dapat meningkatkan pendapatan keluarga manakala mereka kembangkan untuk dikelola secara professional seperti bisnis berjualan bakso.
\end{abstract}

Kata kunci: Nilai tambah, Rumput laut, Diversifikasi

Abstract: The goals and targets to be achieved in this service are to increase the added value of seaweed through skills training and socialization activities. Output generated from this program Increase understanding of the benefits of seaweed, food diversification and fulfillment of family nutrition and skill in making food derived from seaweed into bakso. This training received a very good response from all participants. During the training, participants always came on time and were very enthusiastic in listening to explanations from the servants. The participants were also very active in discussion sessions and many questions were asked. Their knowledge increases with this activity and is very beneficial for everyday life besides being able to help improve skills and also to increase family income when they are developed to be managed professionally such as a business selling meatballs (bakso).

Keywords: Added value, Seaweed, Diversification 
INTEGRITAS : Jurnal Pengabdian

Vol 5 No 1 Juli 2021

ISSN 2580 - 7978 (cetak) ISSN 2615 - 0794 (online)

\section{PENDAHULUAN}

Desa Gelung terletak di Kecamatan Panarukan, Kabupaten Situbondo, Provinsi Jawa Timur. Kabupaten Situbondo merupakan sebuah kabupaten yang memiliki panjang pantai $\pm 168 \mathrm{~km}$ merupakan salah satu Kabupaten yang memiliki potensi sumber daya kelautan dan perikanan cukup besar, khususnya komoditi rumput laut Echeuma cottoni. Oleh karena itu Kabupaten Situbondo juga memiliki peluang besar untuk memacu pendapatan asli daerah melalui sektor kelautan dan perikanan. Hal ini nampak dari keseriusan Pemerintah Kabupaten Situbondo dalam memacu kegiatan pembangunan kelautan dan perikanan dengan menempatkan sektor ini dalam prioritas Perencanaan Pembangunan Daerah.

Desa Gelung merupakan salah satu desa yang ada di Kecamatan Panarukan. Mata pencarian penduduk di desa ini sebagian besar adalah nelayan dan bertani, home industri berupa usaha pembuatan kerupuk dan rengginang. Umumnya di Desa Gelung ini, tidak hanya kaum laki-laki yang bertugas pencari nafkah, melainkan kaum perempuannya pun mengambil bagian dalam menopang ekonomi keluarga. Dengan demikian kaum perempuan pada Desa Gelung telah diperdayakan melaui usaha mencari tambahan penghasilan melalui kegiatan home industri guna memenuhi kebutuhan keluarga sehari hari.

Petani rumput laut dalam kesehariannya bila telah panen hanya menjual dalam bentuk basah yang langsung di timbang dan dijual kepada pedagang yang datang ke desa tersebut. Salah satu upaya untuk meningkatkan nilai tambah produk rumput laut yaitu dengan pemanfaatan rumput laut sebagai bahan baku pengolahan bakso yang siap konsumsi seperti bakso pada umumnya dan kegiatan ini sebelumnya belum banyak dilakukan.

Pengolahan bakso rumput laut merupakan salah satu upaya diversifikasi pengolahan pangan dengan memanfaatkan ketersediaan bahan baku dan karakteristik bahan yang sesuai untuk pengolahan bakso. Penggunaan rumput laut pada pengolahan bakso bertujuan untuk memberi citarasa dengan sumber bahan alami dan meningkatkan kandungan mineral dan vitamin pada produk bakso. Selain itu 
INTEGRITAS : Jurnal Pengabdian

Vol 5 No 1 Juli 2021

ISSN 2580 - 7978 (cetak) ISSN 2615 - 0794 (online)

penggunaan rumput laut bertujuan untuk memperbaiki tekstur bakso, dimana rumput laut dapat membentuk gel pada suhu ruang sehingga dihasilkan bakso yang lebih kenyal, untuk meningkatkan serat pangan sehingga bakso dapat berfungsi sebagai pangan fungsional.

Pengetahuan ibu ibu Desa Gelung tentang diversifikasi pangan masih kurang, oleh sebab itu pencarian atau penggunaan campuran bahan lain selain tepung kanji belum menjadi perhatian/pemikiran dalam membuat bakso. Disamping itu juga latar belakang ibu ibu adalah tamat Sekolah Menengah Pertama dan ada juga Sekolah Dasar, walaupun disatu sisi ada juga yang tamat sekolah menengah atas. (Sulistyaningsih, 2015).

\section{METODE}

Kerangka berpikir untuk memecahkan masalah kegiatan ini digambarkan seperti pada gambar dibawah ini.Dari permasalahan yang muncul disusun berbagai alternatif untuk memecahkan masalah.Selanjutnya dari berbagai alternatif, dipilih alternatif yang paling mungkin dilaksanakan. Berdasarkan kerangka berpikir tersebut, maka metode dalam kegiatan ini adalah sebagai berikut: 
INTEGRITAS : Jurnal Pengabdian

Vol 5 No 1 Juli 2021

ISSN 2580 - 7978 (cetak) ISSN 2615 - 0794 (online)

\section{Permasalahan}

- Ibu ibu Desa Gelung kurang memahami diversifikasi pangan

- Ibu ibu PKK kurang mema hami keterkaitan antara diversifikasi pangan dan gizi keluarga

- Ibu ibu PKK kurang terampil dalam mengolah rumput laut menjadi bakso

\section{Metode Kegiatan}

- Ceramah dan diskusi tentang rumput laut

- Ceramah dan diskusi tentang diversifikasi pangan

- Tanya jawab hubungan antara diversifikasi pangan dan pemenuhan gizi keluarga

- Pelatihan pembuatan makanan dari rumput laut menjadi bakso

\section{Pemecahan Masalah}

- Meningkatkan pengetahuan tentang rumput laut menjadi bakso

- Meningkatkan pengetahuan tentang diversifikasi pangan

- Meningkatkan pengaitan antara diversifikasi pangan dan pemenuhan gizi keluarga

- Menigkatkan keterampilan dalam mengolah rumput laut menjadi makan yang bermutu

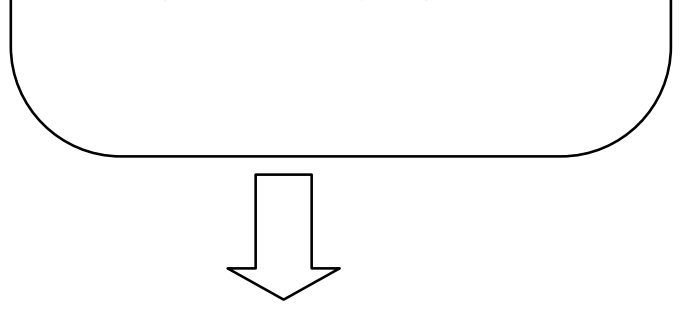

\section{Alternatif Pemecahan Masalah}

- Meningkatkan pemahaman ibu ibu tentang pemanfaatan rumput laut menjadi makanan bermutu melalui ceramah, tanya jawab dan diskusi serta pelatihan pembuatan makanan dari bakso

Gambar 1. Diagram Skematis Metode Kegiatan

\section{HASIL DAN PEMBAHASAN}

Rumput laut dapat dikonsumsi secara langsung maupun diolah menjadi produk olahan lainnya. Di beberapa daerah di Indonesia, beberapa jenis rumput laut telah dimanfaatkan secara turun-temurun oleh masyarakat pesisir, baik untuk dikonsumsi 
INTEGRITAS : Jurnal Pengabdian

Vol 5 No 1 Juli 2021

ISSN 2580 - 7978 (cetak) ISSN 2615 - 0794 (online)

secara langsung dalam bentuk sayuran mentah dan olahan, maupun sebagai bahan manisan dan minuman seperti pada jenis Sargassum sp., Gelidium sp., dan Eucheuma $s p$. Produk hasil olahan rumput laut yang cukup popular dikonsumsi umumnya dalam bentuk pudding, kue, dan sebagai zat aditif makanan (Dwiyitno, 2011 dalam Ratna A.Carolina,2015).

Selain dikonsumsi secara langsung, rumput laut umumnya diolah kembali menjadi bahan baku untuk industri makanan, farmasi dan lain sebagainya. Jika melihat pada data serapan rumput laut oleh industri pengolahan di Indonesia, maka dapat dikatakan bahwa konsumsi rumput laut di Indonesia masih relatif rendah. Dari total produksi rumput laut nasional, sekitar 64\% diekspor dalam bentuk rumput laut kering, sedangkan sisanya sekitar 36\% diserap oleh industri rumput laut didalam negeri (Kementerian Perindustrian, 2015 dalam Ratna A.Carolina,2015).

Rumput laut pada dasarnya budidayakan dan dan dapat dipanen pada umur 40 hari, hasil produknya dapat dipasarkan baik dalam bentuk basah maupun kering serta dapat dijadikan aneka olahan rumput laut dan salah satunya adalah bakso rumput laut.

Pengabdian masyarakat yang dilaksanakan di Desa Gelung Kecamatan Panarukan Kabupaten Situbondo, sebelum pandemic Covid-19 yaitu bulan Pebruari 2020. Masyarakat Desa Gelung umumnya berprofesi sebagai petani dan nelayan, sebagian bekerja swasta.

Target dari sasaran kegiatan adalah ibu-ibu dan secara sengaja pengabdian dilakukan dengan model lesehan dan nyantai sehingga tidak ada kesan menggurui dan ketika acara pelatihan banyak sekali ibu-ibu yang dengan antusias menanyakan perihal deversivikasi pangan yang sebelumnya sudah dijelaskan pada saat ceramah dan diskusi, khususnya terkait deversivikasi rumput laut. Sebagaimana dijelaskan diatas bahwa rumput laut dapat diolah menjadi berbagai macam aneka makanan yang lezat dan bergizi, dan yang pasti banyak disukai oleh masyarakat terutama generasi mellineal, karena rasa dan tampilannya yang menarik. Adapun jenis makanan yang terbuat dan berbahan dasar rumput laut antara lain : Jelly rumput laut, dodol rumput laut, manisan rumput laut, es rumput laut, bakso rumput laut dan lain sebagainya. 
INTEGRITAS : Jurnal Pengabdian

Vol 5 No 1 Juli 2021

ISSN 2580 - 7978 (cetak) ISSN 2615 - 0794 (online)

Adapun bahan yang perlu dipersiapkan dalam pembuatan bakso dan es rumput laut adalah sebagai berikut:

1. daging sapi $2 \mathrm{~kg}$

2. tepung kanji 500 gr

3. rumput laut basah $350 \mathrm{gr}$

4. bawang putih, mrica, garam, bumbu penyedap, secukupnya

5. buah semangka, melon dan nanas

6. sirup

7. rumput laut basah

Cara membuatnya semua bahan digiling jadi satu, dibentuk bola-bola dimasukkan dalam air mendidih setelah matang tiriskan,sementara itu buat kuwah bakso, dengan bumbu bawang putih, merica dihaluskan tumis dengan bawang daun setelah harum tuangi kaldu sapi dan masukkan bakso yang telah matang tadi selanjutnya bakso siap disajikan. Sebagian ibu-ibu mempersiapkan membuat es rumput laut, santan dimasak kemudian didinginkan, buah dikupas dan dipotong kecilkecil, rumput laut (sebelumnya direndam dengan air kapur selama 1malam) di cuci bersih sampai bau amisnya hilang. Semua bahan es ditata dalam gelas dan siap disajikan. Dan dibawah ini di cantumkan beberapa foto-foto kegiatan pelatihan pembuatan bakso rumput laut dan es rumput laut.
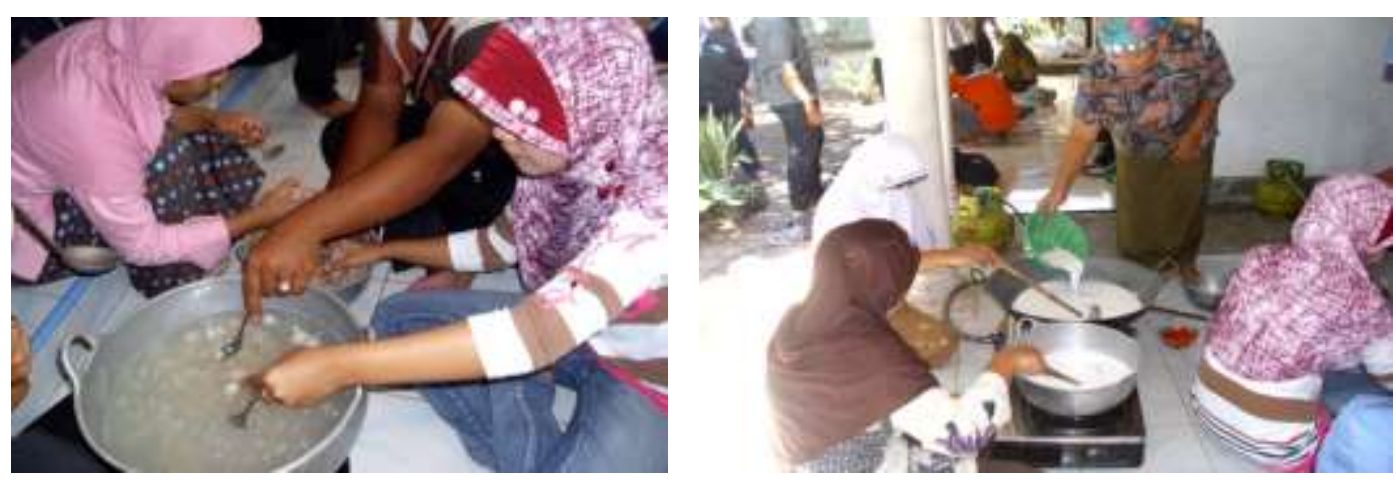

Gambar 2. sebagian Ibu-ibu praktek membuat bakso ruput laut dan sebaian mengolah santan pelengkap es rumput laut 
INTEGRITAS : Jurnal Pengabdian

Vol 5 No 1 Juli 2021

ISSN 2580 - 7978 (cetak) ISSN 2615 - 0794 (online)
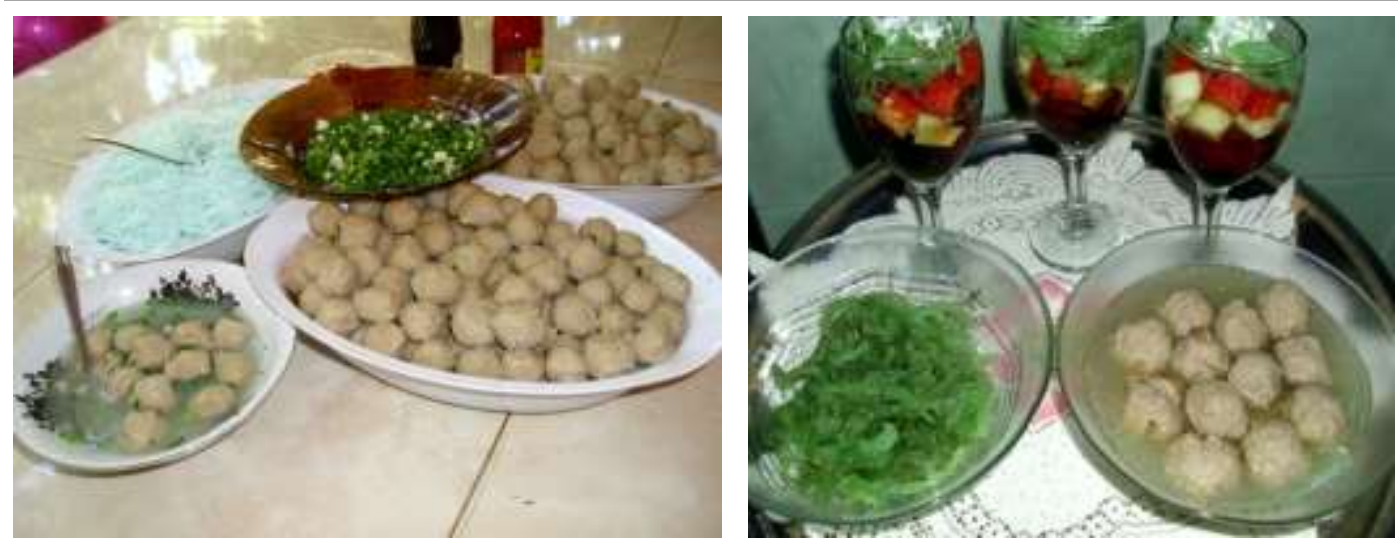

Gambar 3. Bakso dan es rumput laut siap disajikan

Dengan adanya kegiatan pengabdian ini diharapkan terdapat peningkatan daya saing dari produk rumput laut itu sendiri dan pengetahuan masyarakat terkait dengan deversivikasi produk rumput laut semakin bertambah sehingga selain adanya peningkatan kemampuan keterampilan juga secara ekonomi meningkatkan pendapatan mereka.

\section{KESIMPULAN}

Pelatihan ini mendapat respon yang sangat baik dari seluruh peserta.Selama pelatihan, peserta selalu datang tepat waktu dan sangat semangat dalam mendengarkan penjelasan dari para pengabdi. Para peserta juga sangat aktif dalam sesi diskusi dan banyak pertanyaan-pertanyaan yang disampaikan. Diharapkan pengabdian ini memberi kontribusi bagi para peserta sehingga terjadinya peningkatan dalam pengetahuan, keterampilan maupun ekonomi.

\section{Daftar Pustaka}

Anis. 2013."Resep dan Cara Membuat Bakso Rumput Laut yang Mak Yuss". www. webcache.googleusercontent.com diakses tanggal 01 Juni 2016

Dwiyitno. (2011). Rumput Laut Sebagai Sumber Serat Pangan Nasional. Squalen Vol. 6 (1): 9 - 17. Jakarta. 
INTEGRITAS : Jurnal Pengabdian

Vol 5 No 1 Juli 2021

ISSN 2580 - 7978 (cetak) ISSN 2615 - 0794 (online)

Kementerian Perindustrian. (2015). Kebijakan Pengembangan Hilirisasi Industri Pengolahan Rumput Laut 2015 - 2019 (RoadMap Industri Rumput Laut Indonesia).

Ratna A. Carolina, 2015, Info Komoditi Rumput Laut (Konsumsi Dan Pengolahan Rumput Laut), Badan Pengkajian dan Pengembangan Kebijakan Perdagangan, Al Mawardi Prima, Jakarta.

Sulistyaningsih.2015." Pengembangan Desa Ekowisata Terpadu Sebagai Optimalisasi Potensi Pantai Patek Serta Potensi Budidaya Rumput Laut Berbasis Teknologi Informasi Dan Umkm Di Desa Gelung Kecamatan Panarukan Kabupaten Situbondo" Laporan Kegiatan KKN-PPM DIKTI 2015. 